\title{
Inovasi Alarm dan Kedisiplinan Masyarakat dalam Manajemen Pembuangan Sampah Rumah Tangga di Perkotaan
}

\author{
Rianto Nurcahyo \\ Bina Nusantara University \\ rnurtjahjo@,binus.edu \\ Indra Adiputra \\ Bina Nusantara University \\ Febriani Pangestu \\ Bina Nusantara University
}

Naskah diterima: 8 Mei 2020 | Naskah disetujui: 8 Juni 2020

\begin{abstract}
Waste is an invaluable or worthless object within the community, while its issue somehow makes a very serious problem ranging from social, economic, even political aspect of daily lives. Being one of most populated developing countries, it is obvious that Indonesia experiences the problem one of which is caused by the people's unawareness to manage their daily household waste. The purpose of this study is to make a platform to ease the public managing the waste disposal schedule so as not to excessively collect or pile the waste up or even dispose it in improperly, for instance in waterways. Using descriptive analysis method, which is a method used to provide an overview of an object under investigation and collect data without analyzing and drawing conclusions that are open to the public, found the results of this research that it is such a good innovation to be applied within community to discipline people's attitude against the waste problem. It can be concluded that the community needs support and/or facilities for waste disposal. In addition to improving the performance of cleaning staff, this is due to the lack of attention from the local government, which should be able to follow up the waste problem.
\end{abstract}

Keywords: Alarm system, community discipline, innovation, waste problem

\begin{abstract}
Abstrak
Sebagai benda yang tak ternilai atau tak berharga, sampah kerap membuat masalah serius di bidang sosial, ekonomi, bahkan politik dalam kehidupan sehari-hari. Menjadi salah satu negara berkembang yang paling padat penduduknya, Indonesia mengalami masalah yang salah satunya disebabkan oleh ketidaksadaran masyarakat untuk mengelola sampah rumah tangga sehari-hari mereka. Tujuan dari penelitian ini adalah untuk membuat platform yang memudahkan masyarakat untuk mengelola jadwal pembuangan sampah agar tidak menumpuk sampah secara berlebihan atau bahkan membuangnya dengan cara yang tidak benar, misalnya di saluran air. Menggunakan metode analisis deskriptif, ditemukan hasil bahwa penelitian ini merupakan inovasi yang baik untuk diterapkan dalam komunitas untuk mendisiplinkan sikap masyarakat terhadap masalah sampah. Dapat disimpulkan pula bahwa masyarakat membutuhkan dukungan dan/atau fasilitas untuk masalah tersebut. Selain dengan upaya meningkatkan kebersihan, kurangnya perhatian dari pemerintah (daerah) seharusnya dapat menindaklanjuti masalah sampah.
\end{abstract}

Kata kunci: Inovasi, kedisiplinan masyarakat, masalah sampah, sistem alarm 


\section{Pendahuluan}

Berdasarkan data dari Kementerian Lingkungan Hidup dan Kehutanan (KLHK) RI, total sampah di Indonesia tahun 2019 mencapai 68 juta ton lebih, di mana sampah plastik diperkirakan mencapai 9,52 juta ton. Selain itu, kurangnya kesadaran masyarakat dalam membuang sampah sering kali menyebabkan mereka membuang sampah sembarangan, seperti membuang sampah di selokan, sungai, dan pada akhirnya menumpuk di lautan. Hal ini tentu saja mengakibatkan kebersihan lingkungan serta ekosistem laut menjadi rusak. Menurut Sulistiyorini, Darwis, \& Gutama (2016), untuk mencapai kondisi masyarakat yang hidup sehat dan sejahtera di masa yang akan datang, sangat diperlukan adanya lingkungan permukiman yang sehat. Partisipasi masyarakat dalam pengelolaan sampah dapat meningkatkan kesadaran masyarakat akan pentingnya kebersihan lingkungan yang hijau, bersih dan sehat (Sahil dkk, 2016) serta menguatkan inisiatif masyarakat dalam menjaga, memelihara dan meningkatkan fungsi lingkungan.

Meningkatnya nilai konsumsi masyarakat perkotaan dalam memenuhi kebutuhan hidupnya, menjadi penyumbang dari semakin banyaknya sampah yang harus dibuang (Chandra, 2006). Azwar (1990), Hayat \& Zayadi (2018) mengatakan yang dimaksud dengan sampah adalah sebagian dari sesuatu yang tidak dipakai, tidak disenangi atau sesuatu yang harus dibuang yang umumnya berasal dari kegiatan yang dilakukan manusia (termasuk kegiatan industri) tetapi bukan biologis karena kotoran manusia (human waste) tidak termasuk bagiannya. Sampah rumah tangga tidak dapat dianggap kecil dalam kapasitas penyumbang sampah bagi lingkungan. Pertumbuhan manusia yang setiap tahun meningkat, tidak luput dari penyumbang sampah terbesar di berbagai daerah. Hal itu dipengaruhi oleh lingkungan dan karakter masyarakat yang menjadi problem penting dalam memahami dan mengimplementasikan penanganan sampah bagi suatu daerah.

Bertambahnya sampah sejalan dengan meningkatnya pembangunan infrastruktur dan meningkatnya pertumbuhan manusia tanpa diimbangi dengan pola penanganan dan pengelolaan sampah dengan sarana dan prasaran yang memadai (Sudiran, [2005:17] dalam Hayat \& Zayadi (2018). Di samping itu, kemampuan masyarakat berkontribusi dalam pengelolaan sampah juga akan sangat tergantung kepada pendapatan masyarakat (Sulistiyorini et al., 2016). Permasalahan pengelolaan sampah semakin mendesak untuk diselesaikan karena dampak negatif yang ditimbulkannya semakin kompleks (Firmansyah dkk, 2016). Pada ujungnya, sistem pengelolaan persampahan, terutama untuk daerah perkotaan, harus dilaksanakan secara tepat dan sistemastis.

Menurut Aswadi \& Hendra (2011) Pengelolaan sampah adalah suatu bidang yang berhubungan dengan pengendalian bagaimana sampah dihasilkan, penyimpanan, pengumpulan, pengangkutan, pengolahan dan pembuangan sampah yang menggunakan suatu cara yang sesuai dengan prinsip-prinsip pewadahan, pengumpulan, dan muaranya pada TPA (Tempat Penampungan Akhir). Jika salah satu kegiatan tersebut terputus atau tidak tertangani dengan baik, maka akan menimbulkan masalah pada lingkungan. Skema teknik operasional pengelolaan persampahan dapat dilihat pada Gambar 1 berikut ini. 


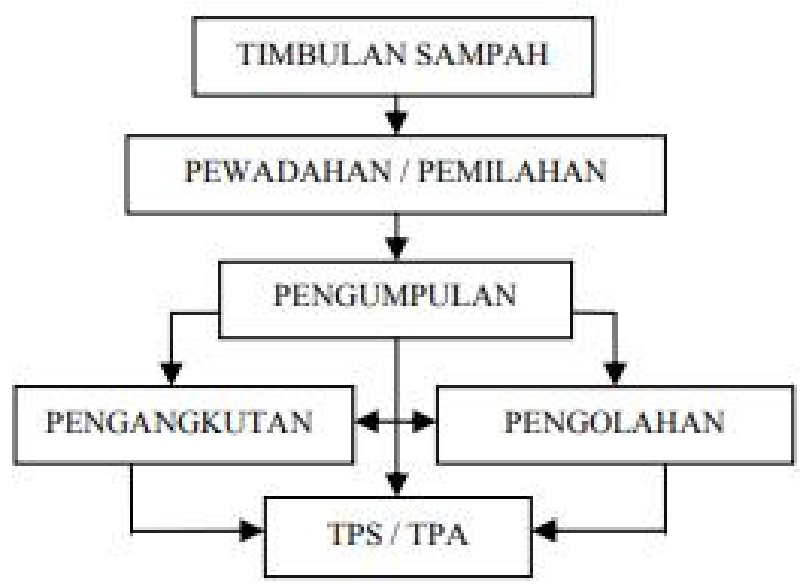

Gambar 1. Skema Teknik Operasional Pengelolaan Persampahan

Sumber : Rizaldi (2008) dalam Aswadi \& Hendra (2011)

Masalah sampah berkaitan erat dengan dengan pola hidup serta budaya masyarakat itu sendiri. Oleh karena itu, penanggulangan sampah bukan hanya urusan pemerintah semata akan tetapi penanganannya membutuhkan partisipasi masyarakat secara luas (Sahil et al., 2016). Fenomena yang terjadi saat ini sesuai dengan penelitian Sahil et al. (2016) bahwa salah satu pengelolaan sampah melalui pengangkutan dengan menggunakan truk, dimana dengan adanya truk pengangkutan sampah di setiap kompleks, kebersihan di sekitar perumahan maupun di jalanan jadi dapat lebih dirawat dan dikelola. Dari hasil wawancara dengan seorang ketua RT di daerah Lenteng Agung Jakarta, Bapak Niman (47 tahun) menjelaskan, "masih ada beberapa masalah yang ditemukan dari pelayanan sampah sehingga tidak jarang pengangkut sampah lalai dalam mengangkut sampah, adanya keterlambatan".

Daerah perkotaan sebagai daerah dengan konsentrasi penduduk yang tinggi merupakan produsen sampah dalam jumlah besar, sehingga tempat pembuangan sampah mutlak diperlukan pada daerah perkotaan. Menurut penelitian yang dilakukan oleh Sahil et al., (2016), keberadaan TPS (Tempat Penampungan Sementara) sebagai sarana pengumpulan sampah sebelum diangkut ke TPA (Tempat Pembuangan Akhir) seringkali menjadi polemik. Warga kerap menolak penempatan TPS di depan rumah mereka, bahkan tak jarang TPS yang telah dibangun justru dibongkar warga. Kondisi TPS yang tidak berpenutup juga merupakan sumber bau busuk dan menjadi penyebab tersebarnya penyakit. Jumlah kontainer sampah masih sangat terbatas, padahal timbulan sampah pasar sangat besar, juga menjadi masalah. Kemudian kekurangan mobil pengangkut juga mengakibatkan keterlambatan diangkutnya sampah dari TPS ke TPA. Pada akhirnya, hal tersebut membuat pelayanan pengangkutan sampah menjadi tidak efisien dan efektif. Banyak aduan dan isu yang dirasakan masyarakat namun tidak tersalurkan ke pemerintah setempat (Nurjaman, Rusman; Prasetyo, 2018). Berangkat dari latar belakang tersebut, penelitian untuk pengabdian masyarakat ini, bertujuan untuk mengatasi masalah sampah masyarakat yang sangat banyak dan menumpuk jika petugas pembuang sampah tidak mengambil sampah tersebut. Berikut merupakan tujuan teknis penelitian ini:

1. Mempermudah masyarakat untuk mengetahui/ mengingat jadwal pembuangan sampah.

2. Mengingatkan/ Melapor jika petugas pembuang sampah belum mengambil sampah.

3. Dapat menanggulangi sampah - sampah yang menumpuk di satu tempat. 
4. Dapat mempermudah masyarakat terutama pelaku rumah tangga dalam membuang sampah dengan secara teratur.

5. Dapat menanggulangi masalah-masalah banjir yang dikarenakan penumpukan sampah akibat buang sampah sembarangan.

6. Dapat menghemat lahan karena lahan sampah dapat dibuat di bawah tanah.

7. Dapat mengurangi dampak buruk yang diakibatkan karena sampah yang menumpuk seperti penyakit dan pencemaran.

\section{Metode Penelitian}

Metode yang digunakan dalam penulisan pengabdian masyarakat ini adalah menggunakan pendekatan penelitian deskriptif, tepatnya menggunakan penelitian deskriptif kualitatif karena peneliti bermaksud untuk menggambarkan secara deskriptif bagaimana pengelolaan sampah melalui analisis objek penelitian yang menjadi uraian serta penjelasan dari data-data yang didapatkan guna diolah menjadi beberapa informasi (Nudiana, Yuningsih, \& Maesaroh, 2014). Metode yang digunakan melalui pengumpulan data terdiri atas pencarian data dan informasi melalui dokumendokumen pendukung, seperti buku, jurnal ilmiah, dan dokumen elektronik dari internet. Adapun tahapan dalam penulisan ini di antaranya perumusan masalah untuk kemudian menjadi gagasan, pengumpulan data dan fakta terkait, verifikasi data dan fakta, analisa konseptual dengan argumentasi yang rasional, perumusan hasil gagasan dan kesimpulan serta rekomendasi terkait penanganan masalah (Sulistiyorini et al., 2016).

\section{Hasil dan Pembahasan}

Persoalan sampah di perkotaan tak kunjung selesai seiring dengan tingginya kepadatan penduduk yang pada akhirnya membuat konsumsi masyarakat pun menjadi semakin tinggi. Namun di sisi lain, lahan untuk menampung sisa konsumsi sangat terbatas. Begitupun dengan fasilitasfasilitas dalam pembuangan sampah seperti tempat sampah, truk pengangkutan sampah, serta pelayanan dalam pengangkutan sampah. Persoalan semakin bertambah ketika disadari bahwa sampah konsumsi warga perkotaan itu ternyata banyak yang tidak mudah terurai, terutama plastik. Semakin menumpuknya sampah plastik menimbulkan pencemaran serius. Kondisi ini belakangan mulai disadari sebagian masyarakat dengan menumbuhkan upaya pengurangan sampah plastik.

Kantong plastik baru dapat mulai terurai paling tidak selama lebih dari 20 tahun di dalam tanah. Jika kantong plastik itu berada di air, akan lebih sulit lagi terurai. Selain itu, kesadaran masyarakat akan pentingnya buang sampah pada tempatnya pun kurang. Banyak masyarakat yang tidak peduli dengan lingkungan membuang sampah sembarangan dan pada akhirnya tumpukan sampah tersebut dapat mengakibatkan banjir dan menjadi penyebab munculnya penyakit. Banyak juga masyarakat yang tidak paham akan pemisahan sampah, yang tak kalah pentingnya, tidak jarang dari masyarakat di suatu perumahan yang tidak mengumpulkan sampah untuk diangkut oleh truk pengangkutan sampah, sampah cenderung ditumpuk saja di sekitar perumahan di mana yang menyebabkan kondisi lingkungan bukannya membaik tapi malah memburuk. Daerah perkotaan penuh dengan sampah - sampah yang menyebabkan lingkungan kumuh dan pemampatan saluran air terutama sungai diperparah juga dengan jarangnya truk sampah yang berkeliling mengambil 
sampah-sampah di perumahan. Sampah mengakibatkan munculnya bau-bau yang tidak sedap ketika terjadi penumpukan sampah serta munculnya bibit penyakit.

Menurut UU Nomor 18 (2008) tentang Pengelolaan Sampah, terdapat 2 kelompok utama pengelolaan sampah, yaitu:

a) Pengurangan sampah (waste minimization), yang terdiri dari pembatasan terjadinya sampah, guna-ulang dan daur-ulang

b) Penanganan sampah (waste handling), yang terdiri dari:

i. Pemilahan: dalam bentuk pengelompokan dan pemisahan sampah sesuai dengan jenis, jumlah, dan/atau sifat sampah

ii. Pengumpulan: dalam bentuk pengambilan dan pemindahan sampah dari sumber sampah ke tempat penampungan sementara atau tempat pengolahan sampah terpadu

iii. Pengangkutan: dalam bentuk membawa sampah dari sumber dan/atau dari tempat penampungan sampah sementara atau dari tempat pengolahan sampah terpadu menuju ke tempat pemrosesan akhir

iv. Pengolahan: dalam bentuk mengubah karakteristik, komposisi, dan jumlah sampah

v. Pemrosesan akhir sampah: dalam bentuk pengembalian sampah dan/atau residu hasil pengolahan sebelumnya ke media lingkungan secara aman.

Berdasarkan hal tersebut di atas, dalam pengelolaan sampah kota di Indonesia, sumber sampah kota dibagi berdasarkan asalnya, seperti permukiman atau rumah tangga dan sejenisnya, pasar, kegiatan komersial seperti pertokoan, kegiatan perkantoran, hotel dan restoran, dan sebagainya. Kemudian sampah dari institusi seperti industri, rumah sakit, serta sampah yang berasal dari fasilitas umum seperti jalan dan taman terbuka.

Menurut Dokumen Badan Pengelolaan Lingkungan Hidup Daerah (BPLHD) Jakarta, akumulasi sampah pada 2016 diperkirakan bisa mencapai 41 juta ton. Menurut Sudiro, Setyawan, \& Nulhakim (2018), pada dasarnya pengelolaan sampah permukiman adalah merupakan bagian yang tak terpisahkan dalam hal pengelolaan sistem sanitasi. Dalam hal pengelolaan sampah secara nasional sudah dibuat suatu kebijakan dan strategi pelaksanaannya, seperti yang tercantum dalam Peraturan Menteri Pekerjaan Umum Nomor: 21/PRT/M/2006 tentang Kebijakan dan Strategi Nasional Pengembangan Sistem Pengelolaan Persampahan. Rumusan kebijakan tersebut antara lain adalah : (1) Pengurangan sampah semaksimal mungkin dimulai dari sumbernya, (2) Peningkatan peran aktif masyarakat dan dunia usaha/swasta sebagai mitra pengelolaan, (3) Peningkatan cakupan pelayanan dan kualitas sistem pengelolaan, (4) Pengembangan kelembagaan, peraturan dan perundangan, dan (5) Pengembangan alternatif sumber pembiayaan. Sementara penelitian yang dilakukan oleh Shi- (2019), menemukan bahwa sampah domestik, baik dari bahan organik maupun anorganik dibuang begitu saja dalam satu bak/wadah dan tercampur satu sama lain dalam berbagai komposisi, dan kemudian melalui berbagai cara transportasi, sampah berpindah tempat mulai dari 2 tempat sampah di rumah, TPS (Tempat Pembuangan Sementara) sampai ke Tempat Pembuangan Akhir (TPA).

Menurut Agus, Oktaviyanthi, \& Sholahudin (2019), mengolah sampah perlu dilakuan dengan konsep 3R yaitu reuse (menggunakan kembali), reduce (mengurangi), dan recycle (mendur ulang). Konsep tersebut merupakan cara untuk mengolah sampah dari hulu dalam artian sampah rumah 
tangga. Mengaplikasikan konsep 3R sebetulnya mudah tapi diperlukan kesadaran masyarakat itu sendiri, maka dari itu diperlukan adanya sosialisasi tentang bahaya sampah terhadap kesehatan dan lingkungan. Dalam teknik ini secara langsung, masyarakat dapat memilah sampah berdasarkan sifatnya agar petugas kebersihan dapat memaksimalkan proses pendaur-ulangan.

Jika memperhatikan informasi yang diperoleh dari Plt Kepala Dinas Lingkungan Hidup DKI Jakarta Andono Warih yang mengatakan bahwa Jakarta setiap harinya memproduksi 7.500 ton sampah dimana mayoritas berasal dari sampah permukiman atau rumah tangga. Dari jumlah tersebut, sekitar 16 persennya tidak bisa terangkut oleh kendaraan dinas kebersihan. Indonesia akan menghasilkan sampah sekitar 66 - 67 juta ton sampah pada tahun 2019. Untuk jumlah ini lebih tinggi dibandingkan jumlah sampah per tahunnya yang mencapai 64 juta ton. Sebelumnya, berdasarkan data The World Bank tahun 2018, 87 kota di pesisir Indonesia memberikan kontribusi sampah ke laut diperkirakan sekitar 1, 27 juta ton. Dengan komposisi sampah plastik mencapai 9 juta ton dan diperkirakan sekitar 3,2 juta ton adalah sedotan plastik.

\begin{tabular}{|l|r|r|}
\hline Kota di Indonesia & Jumlah Produksi & Jumlah yang terangkut \\
\hline Medan & 1700 & $1.564,85$ \\
\hline Jambi & $1.517,1$ & 924,74 \\
\hline DKI Jakarta & $7.099,08$ & $6.016,3$ \\
\hline Semarang & $5.080,51$ & 4.445 \\
\hline Surabaya & $9.710,61$ & $5.237,7$ \\
\hline Denpasar & 3.719 & 3.625 \\
\hline Banjarmasin & 3.471 & $3.331,5$ \\
\hline Samarinda & $3.212,66$ & $2.002,34$ \\
\hline Makasar & $5.913,4$ & $5.623,61$ \\
\hline
\end{tabular}

Tabel 1 Produksi dan volume sampah yang terangkut

Sumber : BPS (2016)

Berdasarkan data tabel 1, bisa terlihat bahwa jumlah sampah yang terproduksi tiap harinya memiliki jumlah yang cukup besar, dan jumlah sampah yang terangkut tiap harinya lebih sedikit dari jumlah sampah yang ada. Dari analisa data primer yang didapat ini, bisa dikatakan bahwa pelayanan pengangkutan sampah di lingkungan masyarakat masih belum berjalan dengan efektif dan efisien.

Untuk memecahkan masalah sampah yang terutama karena kebiasaan masyarakat yang suka membuang sampah sembarangan dengan alasan keterlambatan petugas pengangkut sampah, harus dilakukan suatu tindakan membentuk inovasi. Rogers (dikutip dari Suwarno, 2007: 3) dalam (Lestari, 2014) menjelaskan inovasi adalah sebuah ide, praktek, atau objek yang dianggap baru oleh individu satu unit adopsi lainnya. Menurut Mckeown (dikutip dari Ancok, 2012: 34-35) bahwa inovasi adalah suatu bentuk perubahan dari suatu hal, baik yang bersifat inkremental (sedikit demi 
sedikit), maupun perubahan yang radikal. Penerapan inovasi dalam kehidupan masyarakat akan mendapatkan manfaat dari segi sosial dan ekonomi.

Dalam konteks masalah sampah ini, salah satu inovasi yang dapat dilakukan adalah melalui adanya alarm pelayanan pembuangan sampah. Inovasi Alarm Pelayanan Pembuangan Sampah ini akan berbentuk aplikasi, yang memuat hal-hal berikut:

1) Jadwal pembuangan sampah di lokasi masyarakat

2) Alarm pengingat bahwa truk pembuang sampah akan datang

3) Layanan pengaduan untuk melaporkan bila terjadi sesuatu

4) Layanan pelaporan jika truk/petugas pembuang sampah tidak hadir

5) Layanan berita mengenai pengelolaan sampah

6) Artikel mengenai pengelolaan sampah di Indonesia

Adanya inovasi sistem alarm ini diharapkan membuat masyarakat tidak lagi mempunyai alasan untuk membuang sampah sembarangan. Jika inovasi program ini dijalankan, maka diharapkan akan mengurangi lingkungan kumuh yang penuh sampah terutama di depan rumah masyarakat, karena dengan adanya alarm ini masyarakat dapat mengetahui jadwal, memberikan kritik, melapor jika petugas pengangkut sampah belum tiba atau tidak sesuai jadwal. Sungai dan saluran air akan menjadi lebih lancar dan terus berjalan di bawah tanah sehingga tidak memunculkan bau-bau tidak sedap. Dengan adanya inovasi alarm pelayanan kebersihan sampah ini dapat menjaga masyarakat dari ancaman penyakit dan menjadikan lingkungan bersih dan sehat. Masyarakat rumah tangga tidak perlu lagi menunggu truk sampah yang penjadwalannya tidak teratur dan dengan demikian pola pikir masyarakat dalam membuang sampah akan menjadi lebih baik. Sikap acuh tak acuh masyarakat terhadap sampah dapat dikurangi dengan alarm ini, karena mereka selalu diingatkan dengan jadwal pembuangan sampah.

\section{Konsep Rancangan Miniatur TPA Monitor Sampah Warga}

"Konsep Rancangan Miniatur TPA Monitor Sampah Warga" adalah rumah yang didesain dan dibangun dengan tambahan perangkat lunak (software) yang berguna untuk menginformasikan ke Dinas Kebersihan apabila terdapat sampah. Bagan rangkaian perangkat keras (hardware) ini akan membaca melalui perangkat lunak melalui server, dan dari server ini, alarm akan berbunyi seperti dalam ilustrasi di bawah ini: 


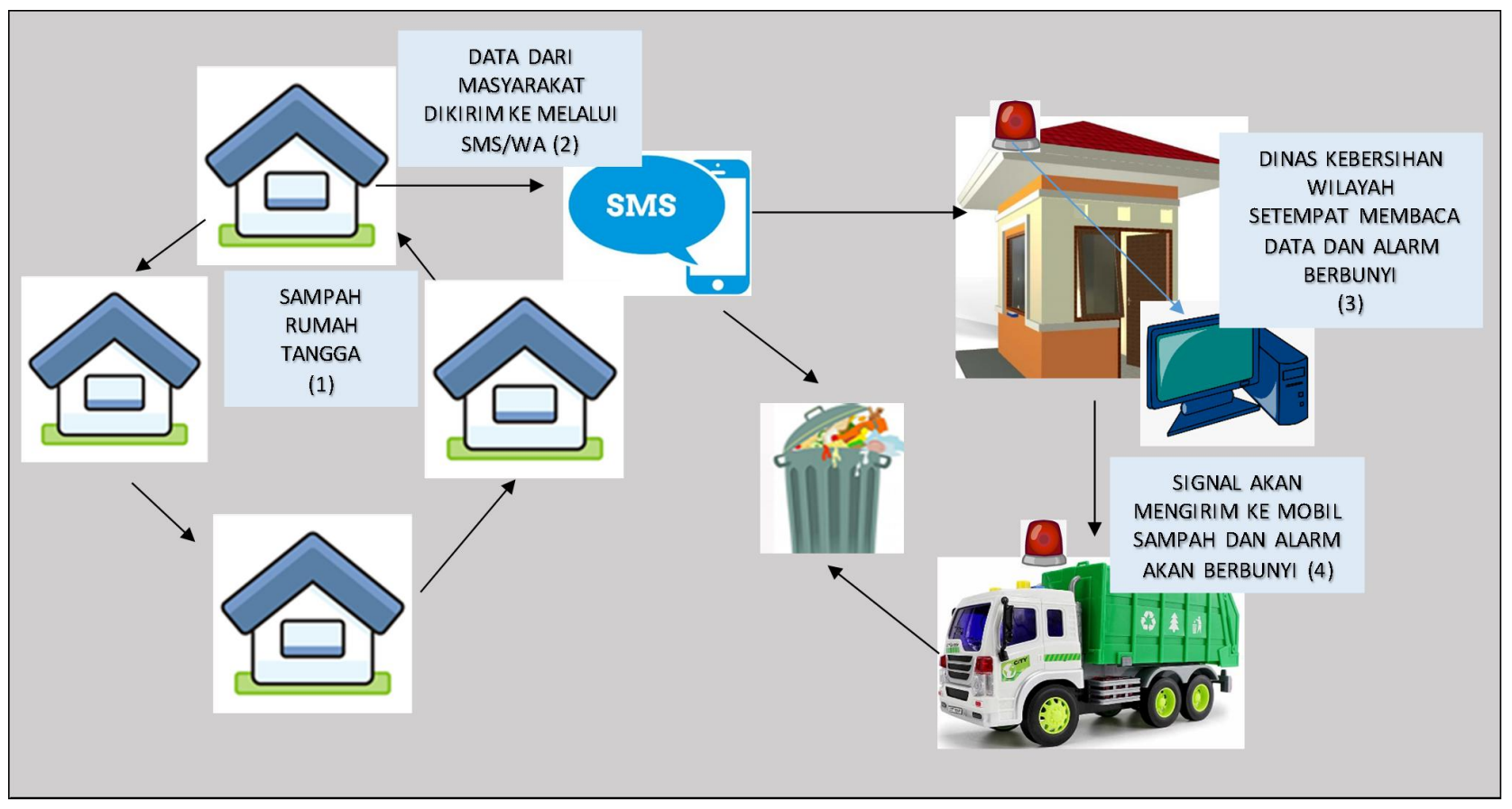

Gambar 2. Konsep Rancangan Miniatur TPA Monitor Sampah Warga

Diharapkan dengan adanya inovasi ini, masyarakat dapat membantu pemerintah untuk lebih mudah mengidentifikasi permasalahan terkait pembuangan sampah, utamanya di pemukiman masyarakat urban, dan dapat menanganinya setanggap mungkin. Pengelolaan sampah dari sebuah kota adalah sebuah sistem yang kompleks dan tidak dapat disejajarkan atau disederhanakan begitu saja, misalnya dengan penanganan sampah di daerah pedesaan yang, misalnya, justru dapat menjadi aset unggulan bernilai ekonomi (Nurhidayati, 2020). Demikian pula keberhasilan upaya-upaya sektor informal saat ini tidak dapat begitu saja diaplikasikan dalam menggantikan sistem formal yang selama ini ada. Dibutuhkan waktu yang lama karena menyangkut juga perubahan perilaku masyarakat serta kemauan semua pihak untuk menerapkannya.

\section{Kesimpulan}

Selama ini, masih banyak masyarakat yang mengeluh dengan tumpukan sampah yang ada di pinggir jalan atau aliran air, salah satunya karena pemerintah kurang mengawasi dan cekatan dalam mengatasi kekurangan truk pengangkut sampah. Hal tersebut juga diperparah oleh masyarakat awam yang gemar membuang sampah sembarangan jika tidak diberi sarana pembuangan sampah yang baik. Adanya inovasi alarm pelayanan kebersihan sampah ini diharapkan dapat meningkatkan kedisiplinan masyarakat dalam menangani sampah dalam kehidupan sehari-hari, serta meningkatkan kinerja pihak yang berwenang, yaitu Dinas Kebersihan melalui petugas truk pengangkutan sampah. Dengan sinergi tersebut, maka permasalahan sampah di lingkungan perumahan perkotaan dapat sedikit banyak terselesaikan. 


\section{Daftar Pustaka}

Agus, R. N., Oktaviyanthi, R., \& Sholahudin, U. (2019). 3R: Suatu Alternatif Pengolahan Sampah Rumah Tangga. Kaibon Abhinaya: Jurnal Pengabdian Masyarakat, 1(2), 72. https://doi.org/10.30656/ka.vli2.1538

Aswadi, M., \& Hendra. (2011). Perencanaan pengelolaan sampah di perumahan tavanjuka mas, Mektek, 13(2), 99-110.

Firmansyah, A., Nur, W., Fatimah, A., \& Mubarokah, U. (2016). Innovation of Garbage Management Based on Community. Prosiding Seminar Nasional Hasil-Hasil PPM IPB, (1), 184-197. Retrieved from http://lppm.ipb.ac.id/wp-content/uploads/2017/06/B503.pdf

Hayat, H., \& Zayadi, H. (2018). Model Inovasi Pengelolaan Sampah Rumah Tangga. Jurnal Ketahanan Pangan, 2(2), 131-141.

Lestari, A. P. (2014). Program Inovasi Pengelolaan Sampah Di Kota Malang. Jurnal Administrasi Publik Mahasiswa Universitas Brawijaya, 2(3), 571-577.

Nudiana, D. F., Yuningsih, T., \& Maesaroh. (2014). Studi kualitatif pengelolaan sampah di kecamatan banyumanik kota semarang.

Nurhidayati, M. (2020). Pelatihan Pengelolaan Sampah Plastik di Dusun Sumber Rejo Desa Lembeyan Wetan Kabupaten Magetan. Amalee: Indonesian Journal of Community Research and Engagement, 1(1), 59-67. https://doi.org/10.37680/amalee.v1i01.175

Nurjaman, Rusman; Prasetyo, A. G. (2018). Pemanfaatan Teknologi Informasi Dan Pemberdayaan Masyarakat Dalam Meningkatkan Pengelolaan Persampahandi Kota Palangka Raya, Jurnal Borneo Administrator, 14(1), 35-52.

Sahil, J., Henie, M., Al, I., Rohman, F., \& Syamsuri, I. (2016). Sistem Pengelolaan dan Upaya Penanggulangan Sampah Di Kelurahan Dufa- Dufa Kota Ternate. Sanitasi Lingkungan, 4(2), 478-487.

Shi-, F. A. N. (2019). 沈青混合料半圆弯曲低温断裂一㸝合特性 1，2 3. 36(12), 57-74.

Sudiro, S., Setyawan, A., \& Nulhakim, L. (2018). Model Pengelolaan Sampah Permukiman Di Kelurahan Tunjung Sekar Kota Malang. Plano Madani : Jurnal Perencanaan Wilayah Dan Kota, 7(1), 106-117. https://doi.org/10.24252/planomadani.v7ila10

Sulistiyorini, N. R. S., Darwis, R. S., \& Gutama, A. S. (2016). Partisipasi Masyarakat Dalam Pengelolaan Sampah Di Lingkungan Margaluyu Kelurahan Cicurug. Prosiding Penelitian Dan Pengabdian Kepada Masyarakat, 3(3), 414. https://doi.org/10.24198/jppm.v3i3.13786 